\title{
Adolescent psychotherapy process research: adaptation of the instrument APQ
}

\author{
Silvia Pereira da Cruz Benetti - Universidade do Vale do Rio dos Sinos (UNISINOS), São Leopoldo, Brasil \\ Georgius Cardoso Eisswein - Universidade do Vale do Rio dos Sinos (UNISINOS), São Leopoldo, Brasil \\ Nathália Bohn da Silva - Universidade do Vale do Rio dos Sinos (UNISINOS), São Leopoldo, Brasil \\ Gabriel Soares Carvalho Bernardi - Universidade do Vale do Rio dos Sinos (UNISINOS), São Leopoldo, Brasil \\ Ana Calderón - University College of London, Londres, Reino Unido
}

\begin{abstract}
The aim of this paper is to present the Brazilian version of the instrument APQ (Adolescent Psychotherapy Q-Set), including its translation and initial adaptation, followed by the construction of psychotherapy prototypes for psychoanalytic and cognitivebehavioral approaches. A total of 10 psychoanalytic and 10 cognitive-behavioral therapists were asked to classify the APQ items in relation to relevance to their theoretical model. Data were analyzed with factor analysis. The extraction of two factors explained $48.07 \%$ of the total variance. The Cronbach's alpha for the psychoanalytic factor was 0.85 and for the cognitivebehavioral factor, 0.86. The former presented factor loadings ranging from .61 to .73, whilst the latter from .49 to .80. The prototypes were developed through linear regression calculations of each APQ item's contribution to each of the factors. It was observed that the two prototypes adequately discriminated psychoanalytic and cognitive behavioral approaches, indicating that the APQ is an appropriate tool for research in psychotherapy.

Keywords: psychotherapy, adolescence, assessment
\end{abstract}

Pesquisa de Processo em Psicoterapia na Adolescência: Adaptação do Instrumento APQ

\begin{abstract}
Resumo
O objetivo deste artigo é apresentar a versão brasileira do instrumento APQ (Adolescent Psychotherapy Q-Set), incluindo sua tradução e adaptação inicial, seguida da construção de protótipos de psicoterapia na adolescência de orientação psicanalítica e cognitivo-comportamental. Solicitou-se a dez psicoterapeutas psicanalíticos e dez cognitivo-comportamentais que classificassem os itens do APQ, considerando sua relevância ao seu modelo teórico. Os dados foram submetidos à análise fatorial. A extração de dois fatores explicou $48,07 \%$ da variância total. O alpha de Cronbach do fator psicanalítico foi 0,85 e do cognitivo-comportamental foi 0,86 . O primeiro fator apresentou cargas fatoriais entre 0,61 a 0,73 e o segundo entre 0,49 a 0,80 . Cálculos de regressão linear identificaram os escores da contribuição de cada item do APQ para cada fator, desenvolvendo-se assim os protótipos. Observou-se que as abordagens psicanalítica e cognitivo-comportamental foram discriminadas, indicando que o instrumento é apropriado para o desenvolvimento de pesquisas em psicoterapia.

Palavras-chave: psicoterapia, adolescência, avaliação
\end{abstract}

Investigación del proceso de psicoterapia en la adolescencia: adaptación del instrumento APQ

\begin{abstract}
Resumen
El objetivo de este artículo es presentar la versión brasileña del instrumento APQ (Adolescent Psychotherapy Q-Set), incluyendo su traducción y adaptación inicial, y la construcción de prototipos de psicoterapia en la adolescencia de orientación psicoanalítica y cognitivo-conductual. Se solicitó a diez psicoterapeutas psicoanalíticos y diez cognitivo-conductuales que clasificasen los ítems del APQ, teniendo en cuenta su relevancia para el modelo teórico. Los datos fueron sometidos a análisis factorial y la extracción de dos factores explicó 48,07\% de la varianza total. El alfa de Cronbach del factor psicoanalítico fue 0,85, y del cognitivo-conductual 0,86. El primer factor presentó cargas factoriales entre 0,61 y 0,73 y el segundo entre 0,49 y 0,80. Cálculos de regresión lineal identificaron los resultados de contribución de cada ítem del APQ para cada factor, desarrollándose así los prototipos. Se observó que el enfoque psicoanalítico y cognitivo-conductual fueron discriminados, indicando que el instrumento es apropiado para el desarrollo de investigaciones en psicoterapia.

Palabras-clave: psicoterapia, adolescencia, evaluación
\end{abstract}

Systematic reviews on the results of psychotherapy have proven the positive impact of psychotherapeutic treatments, indicating evidence of effectiveness and therapeutic efficacy associated with different means of intervention of different theoretical approaches. These studies show that researches in psychotherapy have gone a long way on demonstrating their effectiveness, and contemporary issues turn to process studies, aimed at identifying the various active ingredients of the various forms of psychotherapy (Crits-Christoph, Gibbons \& Mukherjee, 2013; Kazdin, 2007; Shedler, 2010).

The research in psychoanalytic psychotherapy has advanced considerably in the recent decades (Levy, Ablon \& Kächele, 2012). Midgley and Kennedy 
(2011) state that, initially, researches in psychoanalytic psychotherapy were viewed as having gaps in scientific evidence regarding the effectiveness of the interventions. However, in recent decades there has been a growing increase in the number of researches on psychoanalytic psychotherapy with positive evidence over the interventions (Crits-Christoph et al, 2013;. Shedler, 2010). However, there is still only a small number of works focusing on childhood and adolescence (Midgley \& Kennedy, 2011; Tonge, Pullen, Hughes \& Beaufoy, 2009), mainly focused on describing processes and therapeutic results in order to answer why and how psychotherapy works, considering the identification of elements involved in the therapeutic change in different clinical cases and age groups (Midgley, 2008).

Still, this area of research needs to be expanded, mainly through systematic studies aimed at understanding the active elements of therapeutic change. To accomplish this, this goal's central axis would be the development of techniques and tools to evaluate the characteristics of the therapeutic process.

Considering the aspects of improvement in psychotherapy studies in childhood and adolescence based on systematic evaluation of the therapeutic process, this paper presents the Brazilian version of the APQ instrument (Adolescent Psychotherapy Q-Set, Bychkova, Hillman, Midgley, \& Schneider, 2011; Calderón, 2014). The APQ allows the study of the psychotherapeutic process by identifying how change happens throughout the process, pointing out the mechanisms of action of therapeutic models regarding actions and behaviors of the therapist, the patient and the interaction between them. Thus, the instrument enables the development of researches focusing on factors associated with change in different outlines of psychotherapy research. Thus, through this article we intend to contribute to the improvement and consolidation of psychotherapy research, nationally.

\section{Adolescent Psychotherapy Q-Set}

The APQ originated from the PQS (Psychotherapy Process Q-Set, Jones, 1985), an instrument based on the Q-sort method for investigating the characteristic features of therapeutic models. According to Levy, Ablon and Kächele (2012), the use of the instrument has an important characteristic, which is to ensure the depth and complexity of the case analysis, a fundamental premise in psychoanalytic research, while systematically generating empirical data.
The PQS has been validated in Brazil by Serralta, Nunes and Eizirik (2007), and was developed to facilitate the understanding of how change happens in the therapeutic process, pointing out the mechanisms of action of both the therapist and the patient. The instrument has been used on studies on the therapeutic process of different psychotherapies, predictors of the results of psychotherapies, the specifics of the treatment phases and determination of treatments prototypes.

In the last decade, the PQS has been adapted for use with children, Child Process Q-Set (CPQ) (Schneider \& Jones, 2004) and adolescents, Adolescent Psychotherapy Q-Set (Bychkova et al., 2011, Calderón, 2014). Like the PQS, the APQ has 100 session description items. These items were developed to avoid that the session evaluators incur inferences or theoretical judgments, allowing greater validity and reliability. There are statements about the mechanisms of action of the therapist and of the patient, as well as the interaction between them in therapy sessions. However, despite the instrument's intended neutrality with regard to any particular psychotherapy theory, including the description of a wide range of events, interventions, and processes that occur during psychotherapy, the descriptions also allow a comprehensive analysis of what occurs in the session based on different theoretical approaches. For example, Item 90- dreams or fantasies are discussed-, relates to a psychoanalytic approach. But Item 49- There is discussion of specific activities or tasks for the patient to try outside the session-, is more relevant on a cognitivebehavioral approach. Still, these aspects may be present in any therapy, with greater or lesser importance. The authors also point out that although the APQ is based predominantly on descriptions of the psychoanalytic and cognitive-behavioral approaches, there are also descriptions of some emerging psychotherapy methods such as Mentalization and Interpersonal (Bychkova et al., 2011).

The evaluated unit is the whole therapeutic session, recorded or filmed. The evaluation of items is based on the Q-Sort method, and is carried out by judges who are independent and trained in the use of the instrument. More specifically, the Q-Sort method is a set of statements about a particular topic (may include figures) which the subjects must rate, ranging from +5 (total agreement with the statement) to -5 (total disagreement). More specifically in the APQ, as well as in PQS and CPQ, the items are distributed on a continuum from the least characteristic (category 1) to the most characteristic (category 9). The distribution 
of the items in each category is fixed so as to maintain compliance with the standard curve.

After evaluation of the sessions, the responses of different judges (assessors) are sorted and compared, requiring the value of 0.7 in the correlation between the answers in order to obtain a reliability index in the evaluation. Thus, more or less protruding items of the session are identified, both in relation to the patient, the therapist, and the interaction. These analyses enable descriptive interpretations of the sessions and also the extraction of factors that help identify patterns of interaction in the process, and factors that identify similarities between responses. Therefore, the purpose of the evaluation of the therapeutic session is to complete, in a systematic way, a description of the process which can be applied in comparative, or pre and post-test surveys. Similarly, this measure has been used in unique case designs and randomized clinical trials in varied intervention models (Ablon, Levy, \& Smith-Hansen, 2011).

Other possible studies based on the use of the instrument is the development of descriptive models or prototypes for treatments, which do not refer to a specific case, but to an ideal description of how the therapeutic process occurs in a given approach. Meaning that based on the instrument items, one can create a prototype or ideal model of therapy session, according to the assessments of experts on different theoretical approaches. Thus, the assessments of a specific process of a case can be correlated with an ideal prototype of psychotherapeautic approach, checking whether or not there was adherence to the model. Thus, the development of prototypes increases the possibility of analysis of the therapeutic process, since beside the specific mechanisms of action of the investigated case, we can see how much the therapy corresponded to the proposed theoretical approach (Bychkova et al., 2011; Serralta et al., 2007). In the study of Serralta, Pole, Nunes, Eizirik and Olsen (2010) on a case of brief psychoanalytic psychotherapy it was soon observed that certain patient's symptoms were related to the therapist's adherence to either the psychodynamic or the cognitive model throughout the sessions. The implication of the interaction characteristics between patient and therapist due to his diagnosis depending on the psychotherapeutic technique raises an important issue in the process' studies.

In the study on the first development and evaluation of the psychometric properties of the APQ, which was developed in the Anna Freud Centre
(Bychkova et al., 2011; Calderón, 2014), the clinical relevance of the instrument was established with the contribution of 18 psychotherapists from different countries and different theoretical approaches. In this study, they developed prototypes for psychotherapy with adolescents in both the cognitive-behavioral and psychoanalytic approaches, and also the therapeutic models for psychotherapy based on imagery and psychodynamics. Each prototype corresponded to their respective theoretical model, indicating that the instrument differentiated the major characteristics of each therapeutic action.

Recognizing the importance of developing instruments aimed at the study of the therapeutic process, the purpose of this article is to present the Brazilian version of the instrument Adolescent Psychotherapy Q-Set (APQ), starting with describing the translation and adaptation process, taking into account the Brazilian linguistic and cultural context. Secondly, we discuss the primary analysis of validity of the instrument's content through the construction of adolescence psychotherapeutic treatment prototypes both in the psychoanalytic and the cognitive-behavioral approach.

\section{Method}

This study was conducted in a two-step process. The first was the translation and cultural adaptation of the instrument, originally written in English. Secondly, the adolescence psychotherapy prototypes were developed under the perspective of psychoanalytic and cognitive-behavioral approaches as recommended by psychologists and psychiatrists who work with adolescents in these areas.

\section{Step 1: Translation and Adaptation}

First, we requested authorization to the authors of the instrument to formulate the Brazilian version of the APQ instrument. Once permission was obtained, we started the adaptation of the instrument, seeking to comply with the appropriate language standards such as semantic equivalence, relevance and adequacy of meaning, considering the social and cultural characteristics between English and Portuguese languages (Borsa \& Banner, 2014; Cassepp-Borges, Balbinotti \& Theodore, 2010). Thus, the translation has been through the following steps: a) translation of the APQ instrument by two bilingual translators; $b$ ) evaluation by professionals, c) back-translation by bilingual translator; d) submission of the instrument's version to the author, e) finalizing 
the Portuguese version, $\mathrm{f}$ ) verifying instrument content validity in the psychoanalytical approach by developing an initial prototype of adolescence psychoanalytic psychotherapy.

The English version of the translation was done by a professional with proficiency in English and certified by a bilingual professional, both with degrees in psychology. After this first translation, all items were discussed between the research group and the translators. The first Portuguese version was then discussed with two clinical psychologists and four psychology graduate students to identify the idiomatic expressions present in the Brazilian cultural context. Some peculiarities were found, since words in Portuguese have gender, a characteristic absent in the English language, so we opted for neutrality whenever possible.

The aspects that required further analysis and discussion referred to the adaptation of items containing idioms, slang and words that are rarely used in Portuguese. On these occasions, we sought the most approximate translation, with the greater significance in relation to the original. Here are some examples of items that were more modified as a result of the sociocultural adaptation. For example, the English word "date" meaning a romantic encounter would be literary translated as "flerte" (flirtation). This expression, however, is no longer in everyday use and was replaced by "paquera" (item 77). Another item that caused difficulty when translated into Portuguese was the expression "sense of agency". In the first version, this word was translated as "agenciamento" (agencying). In the final version, after a group discussion, we chose the word "empreendedorismo" (entrepreneurship) to better communicate the idea of development/ action (item 28). After this, the instrument was backtranslated to English and the new version was sent to the authors. This version was approved by the authors without any recommendation to modify items. After the authors' approval we elaborated the final version of the instrument.

\section{Development of prototypes}

To develop the adolescence psychotherapy prototypes, 10 therapists with psychoanalytical orientation and 10 therapists with cognitive-behavioral orientation were asked to answer the items in the APQ, classifying their relevance or characteristic with regard to their own theoretical model, in addition to some issues of their professional training. We made contact over e-mail, and the therapists were selected based on convenience and expertise in the area. The questions and the instrument were self-administered and were organized and distributed using the Google Docs ${ }^{\circledR}$ tool. This tool allows one to edit forms and distribute virtually and with confidentiality. All responses were coded and typed into the SPSS software, version 19.

\section{Participants}

The sample of professionals with psychoanalytical orientation consisted of 10 participants with an average age of $\mathrm{M}=42$ years $(\mathrm{SD}=11.86)$. Nine professionals $(90 \%)$ specialize in the area, and five have doctorates $(50 \%)$. The average clinical experience is $\mathrm{M}=17$ years $(\mathrm{SD}=10.60)$ of work. The sample of cognitive-behavioral orientation was comprised of 10 professionals with an average age of $\mathrm{M}=34$ years $(\mathrm{SD}=7.90)$. All the professionals have expertise in the area, four have doctorates $(40 \%)$, and $1(10 \%)$ has a postdoc. The average clinical experience is $\mathrm{M}=9.7$ $(\mathrm{SD}=6.92)$ years of work.

\section{Instruments}

Socio-demographic data and professional experience- The file contained information such as gender, age, education and professional performance, and extent of experience in the profession.

Adolescent Psychotherapy Q-Set (APQ, Bychkova et al, 2011; Calderón, 2014) - The instrument is an adaptation of the PQS (Jones, 1985) and CPQ (Schneider \& Jones, 2004). It consists of 100 items covering different therapist characteristics $(n=40)$, adolescent $(n=30)$ and the interaction between them $(\mathrm{n}=30)$, describing observable behaviors or clear linguistic markers, so as to avoid inferential categorizations. The items are presented as individual cards or in an Excel file, composed by item or a descriptive statement, followed by illustrative examples. The cards are reviewed by the evaluators and arranged in a row of nine categories. At one end are placed the cards that the evaluator believes are the most characteristic (category 9), with respect to their understanding of the material. At the other end, the evaluator puts those cards believed to be the least characteristic (category 1) with regard to the description. Other categories follow in a continuum to the center, where the neutral cards are laid (not outstanding in that session). The categories are as follows: categories 9 and 1 (5 cards), Category 2 and 8 ( 8 cards) categories 7 and 3 (12 cards), categories 6 and 4 (16 cards) and category 5 (18 cards). This way a normal distribution of answers is forced. 
Data analysis- The reliability of the instrument was obtained by calculating Cronbach's alpha. The prototypes have been created considering the Q-technique method, that permits the analysis of opinion segments, highlighting similarities and differences (Bambery, Porcerelli, \& Ablon, 2007). The factors result from the correlation between the data from a smaller number of participants and a significant number of items. To perform this type of analysis it is required to transpose the data, and so the therapists become the items. This strategy correlates a large number of items, but a small number of subjects. After analyzing the main components, we used the Varimax rotation to determine the extraction of two factors. Finally, a linear regression calculation is carried out for each item, identifying their contribution to the model.

\section{Results and discussion}

The responses of ten psychoanalytic psychotherapists and ten psychodynamic on 100 APQ items formed the database to be analyzed. To perform the calculation of the prototypes by Q-technique method the database was inverted and the participant therapists became items. Thus, there was a large number of items, but a small number of subjects. The Cronbach's alpha scale of items relating to the psychoanalytic orientation participants was 0.85 and to the participants of cognitive-behavioral orientation it was 0.86 . The principal component analysis, using Varimax rotation and forcing a solution to two factors presented a $\mathrm{KMO}$ of 0.81 and the Bartlett test, $c 2=1369.11, \mathrm{p}<0.000$. The two factors explained $48.07 \%$ of the total variance. The first factor bundled participants of psychoanalytic orientation with factor loadings ranging from .61 to .73. In turn, the second factor referred to the participants of cognitive-behavioral orientation and presented factor loadings ranging from .49 to .80 . Table 1 shows the factor loadings for each factor.

After extraction of the two factors through linear regression the contribution scores were calculated for each of the 100 APQ items for each of the factors, identifying the items that are more and less important to the model. Tables 2 and 3 show the scores of each of the items in the factors in the psychoanalytic prototype and in the cognitive-behavioral prototype.

The analysis of the most relevant items of the psychoanalytic psychotherapy prototype for adolescents pointed to the following model characteristics. The therapist's action is through a non-critical and neutral position (items 81, 21) when facing the material brought by the adolescent (item 18). The adolescent's defenses are pointed out when the therapist works the feelings that are considered unacceptable (item 50), as well as repetitive patterns (item 62), highlighting the role or past behavior situations (item 92), dreams

Table 1

Factor loading of the rotated components from the analysis of the main APQ components

\begin{tabular}{|c|c|c|c|}
\hline Participants & $\begin{array}{c}\text { Factor } 1 \\
\text { Cognitive Behavioral } \\
\text { Prototype }\end{array}$ & Participants & $\begin{array}{c}\text { Factor } 2 \\
\text { Psychoanalytical } \\
\text { Prototype }\end{array}$ \\
\hline Cognitive 1 & .672 & Psychoanalytic 1 & .610 \\
\hline Cognitive 2 & .540 & Psychoanalytic 2 & .609 \\
\hline Cognitive 3 & .720 & Psychoanalytic 3 & .666 \\
\hline Cognitive 4 & .550 & Psychoanalytic 4 & .623 \\
\hline Cognitive 5 & .679 & Psychoanalytic 5 & .763 \\
\hline Cognitive 6 & .800 & Psychoanalytic 6 & .684 \\
\hline Cognitive 7 & .683 & Psychoanalytic 7 & .632 \\
\hline Cognitive 8 & .490 & Psychoanalytic 8 & .635 \\
\hline Cognitive 9 & .637 & Psychoanalytic 9 & .730 \\
\hline Cognitive 10 & .738 & Psychoanalytic 10 & .602 \\
\hline
\end{tabular}

Extraction Method: Main Component Analysis.

Rotation Method: Varimax with Kaiser Normalization 
and fantasies of the adolescent (item 90). At the same time, there is special attention to the development and maintenance of the therapeutic alliance, exemplified by the care when faced with intense feelings or impulses (items 37 and 47) and facing the feelings on pauses, interruptions or termination of psychotherapy (items 75). The therapist also highlights the characteristic way the adolescent has of dealing with emotions (item 60). Clinical work includes the developing of an attitude of reflection over the problems once the therapist presents a different perspective over an experience (item 80) and questions the views of the adolescent (item 99), working to make sense of their experience (item 09). Self-image is a point of discussion (item 35), as well as current emotional states (item 96), such as romantic love (item 64) and the impact of young people's behavior on others (item 69).

Analyzing the most relevant items of the psychoanalytic psychotherapy prototype in relation to the studies by Bychkova et al. (2011) and Calderon (2014) we can observe important convergence areas when assessing the participant therapists. In this study, among the ten most relevant items of the psychoanalytic psychotherapy prototype, seven are within the most characteristic items of psychoanalysis with adolescents that were identified by Bychkova et al. (2011). The items focusing on transference aspects were not assessed in the top ten, although they were present in the prototype. Below is a table with the average rating of the five most and least characteristic items of the prototype and their factor loadings contribution for the prototype.

Analyzing the most relevant or characteristic items of the adolescence cognitive-behavioral psychotherapy prototype pointed to the following understanding of the therapeutic action: there is attention regarding the therapeutic alliance, as the therapist is concerned with the interaction with the patient (item 47), which features mutual understanding of the therapist and the patient about a particular event or feeling (item 38). The therapist chooses to adopt either a problem solving approach with the adolescent (item 82) or a psychoeducational approach (item 33), explaining the reasons behind his technique (item 57). Also if he actively structures the session (item 17), communicates clearly with the adolescent (item 46), considers the emotional state of the adolescent (item 96), challenges absolute beliefs (item 71) and is directly encouraging (item 66) especially to reflect on their inner emotions, their behavior and that of others (items 97, 85 and 86). There are discussions at the session on specific activities for the adolescent to try outside the session (item 49) and treatment goals (item 04), and is characteristic to discuss material from previous sessions (item 56). Similarly to previous studies, the cognitive and relevant items of the prototype describe the technical aspects of a cognitive-behavioral approach with emphasis on working on the patient's belief system and the therapist's psychoeducational

Table 2

Items more/less characteristic - psychoanalytic prototype

\begin{tabular}{|c|c|c|c|c|}
\hline Item & & More characteristic & $M(S D)$ & Load \\
\hline 75 & $\mathrm{~T}$ & $\begin{array}{l}\text { Therapist pays attention to young person's feelings about breaks, interruptions or } \\
\text { endings in therapy }\end{array}$ & $8.2(0.63)$ & 1.51 \\
\hline 80 & $\mathrm{~T}$ & Therapist presents an experience or event from a different perspective & $8.1(0.56)$ & 1.44 \\
\hline 90 & I & Young person's dreams or fantasies are discussed & $7.6(1.07)$ & 1.40 \\
\hline 37 & $\mathrm{~T}$ & $\begin{array}{l}\text { Therapist remains thoughtful when faced with young person's strong affect or } \\
\text { impulses }\end{array}$ & $8.4(0.51)$ & 1.32 \\
\hline 50 & $\mathrm{~T}$ & Therapist draws attention to feelings regarded by young person as unacceptable & $7.8(0.78)$ & 1.31 \\
\hline \multicolumn{5}{|c|}{ Less characteristic } \\
\hline 66 & $\mathrm{~T}$ & Therapist is directly reassuring & $3.9(2.18)$ & -2.13 \\
\hline 76 & $\mathrm{~T}$ & Therapist explicitly reflects on own behaviour, words or feelings & $3.7(2.40)$ & -2.70 \\
\hline 33 & $\mathrm{~T}$ & Therapist adopts a psychoeducational stance & $2.9(1.85)$ & -2.97 \\
\hline 81 & $\mathrm{~T}$ & Therapist reveals emotional responses & $2.2(1.81)$ & -3.12 \\
\hline 21 & $\mathrm{~T}$ & Therapist self-discloses & $2.5(1.50)$ & -.90 \\
\hline
\end{tabular}


Table 3

Items more/less characteristic items - cognitive-behavioral prototype

\begin{tabular}{lllll}
\hline Item & \multicolumn{1}{c}{ More characteristic } & M(SD) & Load \\
\hline 82 & T & Therapist adopts a problem solving approach with young person & $8.7(0.67)$ & 1.84 \\
49 & I & $\begin{array}{l}\text { There is discussion of specific activities or tasks for the young person to attempt } \\
\text { Outside of session }\end{array}$ & $8.7(0.48)$ & 1.78 \\
& & & \\
57 & T & Therapist explains rationale behind technique or approach to treatment & $8.4(0.96)$ & 1.67 \\
33 & T & Therapist adopts a psychoeducational stance & $8.5(0.70)$ & 1.60 \\
04 & I & Young person's treatment goals are discussed & $9(0.00)$ & 1.53 \\
& & Less characteristic & $4.7(2.26)$ & -1.74 \\
12 & I & Silences occur during the session & $4(1.82)$ & -2.27 \\
51 & I & Young person attributes own characteristics or feelings to therapist & $3.8(2.61)$ & -2.36 \\
14 & I & Young person does not feel understood by therapist & $3.7(1.94)$ & -2.50 \\
45 & I & Young person is concerned about his or her dependence on the therapist & $3.2(2.04)$ & -2.67 \\
44 & I & Young person feels wary or suspicious of the therapist &
\end{tabular}

posture (Bychkova et al., 2011, Calderón, 2014). Below is a table with the average rating of the most and least characteristic 5 items of the prototype and the factor loadings contribution for the prototype.

One can observe that the development of prototypes of psychoanalytic psychotherapy and cognitive behavioral therapy indicated that the APQ instrument has discriminatory capability of the standards of the therapeutic action of the investigated approaches, evidenced by the factors identified by factorial data analysis. This capability can be further verified by the prominent strategies in each of the prototypes which are based on the theoretical assumptions of each approach. Accordingly, the instrument content validity was also confirmed. In the psychoanalytic prototype the attention to defenses, fantasies, repetitive patterns in interactions and strategies of reflection over problems was emphasized, sustained on an attitude of neutrality. In turn, the cognitive behavioral prototype highlighted a more structured approach, opting for psychoeducational interventions, outlining tasks and directly confronting the issues. The concern with developing a therapeutic alliance is present in the two models, an important issue with teenagers who are more subject to abandoning the treatment too early.

\section{Final Considerations}

Encouraging the development of a systematic research in psychotherapy is an important step in the clinical improvement of psychotherapy work in all theoretical approaches. In this paper, we focus on the interest of developing psychoanalytic researches, specifically aimed at the adolescent age group. To this end, we present the Adolescent Psychotherapy Q-Set (APQ), including the adaptation of the Brazilian version of the instrument, first considering the process of translation and adaptation, followed by preparation of the psychotherapeutic treatment prototypes for adolescents in both psychoanalytic and cognitive-behavioral approaches.

Based on the results of these two steps, we observed that the APQ instrument significantly delimited ideal models of psychotherapeutic treatment in the two approaches investigated, pointing to the characteristics in each of them in relation to the therapist's action strategies, the contribution of the patient and the interaction between them. Thus, it was possible to establish psychometric criteria that indicate the instrument's ability to discriminate the ingredients of the therapeutic action of the investigated approaches. This feature allows the development of studies of adhesion to the models, as well as identification of elements of the therapeutic process over the sessions, be it short or long term psychotherapy.

This work intends to collaborate with the expansion of the researches in psychotherapy, particularly towards the study of different interventions and diagnostics. It is also important to stress out it's importance to the development of further researches that are aimed at developing other prototypes and comparative studies of prototypes, for example, comparing professionals 
with higher and lower clinical experience with the working techniques.

\section{References}

Ablon, J. S., Levy, R. A., \& Smith-Hansen, L. (2011). The contributions of the Psychotherapy Process Q-set to psychotherapy research. Research in Psychotherapy: Psychopathology, Process and Outcome, 14(2), 14-48. Retrieved from: http://www.researchinpsychotherapy.net/index.php?journal $=$ rpsy\&page $=$ article \&op $=$ viewFile\&path $\% 5 \mathrm{~B} \% 5 \mathrm{D}=46$ \&path $\% 5 \mathrm{~B} \%$ $5 \mathrm{D}=35$

Bambery, M., Porcerelli, J. H., \& Ablon, J. S. (2007) Measuring psychotherapy process with the adolescent with the Adolescent Psychotherapy Q-set (APQ): development and applications for training. Psychotherapy: Theory, Research, Practice, Training, 44(4), 405-422. doi: 10.1037/0033-3204.44.4.405

Borsa,J.C., \& Bandeira,D. R. (2014). Adaptação transcultural do questionário de comportamentos agressivos e reativos entre pares no Brasil. Psico-USF, 19(2), 287-296. doi: 10.1590/1413-82712014019002015

Bychkova, T., Hillman, S., Midgley, N., \& Schneider, C. (2011). The psychotherapy process with adolescents: a first pilot study and preliminary comparisons between different therapeutic modalities using the Adolescent Psychotherapy Q-Set. Journal of Child Psychotherapy, 37(3), 327-348. doi: 10.1080/0075417X.2011.614754

Calderón, A. (2014). Development and validation of the Adolescent Psychotherapy Q-set (APQ). (Doctoral thesis, University College London, London, $\mathrm{UK})$.

Cassepp-Borges, V., Balbinotti, M. A. A., \& Teodoro, M. L. M. (2010). Tradução e validação de conteúdo: Uma proposta para a adaptação de instrumentos. In L. Pasquali (Org.), Instrumentação psicologica: Fundamentos e prática, 506-520.

Crits-Christoph, P., Gibbons, M. B. C., \& Mukherjee, D. (2013). Psychotherapy process-outcome research. In M. J. Lambert (Ed.), Bergin and Garfield's Handbook of Psychotherapy and Behavior Change (pp. 298-340). London: John Wiley \& Sons Inc.

Jones, E. E. (1985). Manual for the Psychotherapy Process Q-Set. University of California at Berkeley, unpublished.
Kazdin, A. E. (2007). Mediators and mechanisms of change in psychotherapy research. Annual Review of Clinical Psychology, 3, 1-27.doi:10.1146/ annurev. clinpsy.3.022806.091432

Levy, R. A., Ablon, J. S., \& Kächele, H. (2012). Psychodynamic psychotherapy research: evidence-based practice and practice-based evidence. Psychotherapeut, 57, 193-194.

Midgley, N. (2008). Overview of the research on individual child and adolescent psychodynamic psychotherapy. In: Carlberg, G., Eresund, P., \& Boëthius, S. B. (Eds.) Child and Adolescent Psychotherapy Research. Stockholm: Ericastiftelsen, 8-13.

Midgley, N., \& Kennedy, E. (2011). Psychodynamic psychotherapy for children and adolescents: a critical review of the evidence base, Journal of Child Psychotherapy, 37(3), 232-260. doi:10.1080/007541 7X.2011.614738.

Schneider, C., \& Jones, E. E. (2004). The development of the Child Psychotherapy Q-set. Dissertation Abstracts International: Section B: The Sciences and Engineering, 65(2B). California at Berkeley, unpublished.

Serralta, F. B., Nunes, M. L. T., \& Eizirik, C. L. (2007). Elaboração da versão em português do Psychotherapy Process Q-set. Revista de Psiquiatria do Rio Grande do Sul, 29(1), 44-55.

Serralta, F. B., Pole, N., Nunes, M. L. T., Eizirik, C. L., \& Olsen, C. (2010). The process of change in brief psychotherapy: Effects of psychodynamic and cognitive-behavioral prototypes. Psychotherapy Research, 20, (5):564-75. DOI: 10.1080/10503307.2010.493537.

Shedler, J. (2010). The efficacy of psychodynamic psychotherapy. American Psychologist, 93, 68-109. doi: $10.1037 / \mathrm{a} 0018378$.

Tonge, B. J., Pullen, J. M., Hughes, G. C., \& Beaufoy, J. (2009). Effectiveness of psychoanalytic psychotherapy for adolescents with serious mental illness: 12 month naturalistic follow-up study. Australian and New Zealand Journal of Psycbiatry, 43, 467-475. doi:10.1080/00048670902817679

Recebido em: 15/08/2015 Reformulado em: 14/03/2016 Aceito em: 21/03/2016 
Sobre os autores:

Silvia Pereira da Cruz Benetti é psicóloga formada pela Universidade Federal do Rio Grande do Sul (1980), possui título de doutor em Psicologia pela Syracuse University, USA (1999) e professora adjunta do Curso de Psicologia e do Programa em Pós-Graduação em Psicologia da Universidade do Vale do Rio dos Sinos (UNISINOS) - São Leopoldo, RS.

E-mail:sbenetti@unisinos.br

Georgius Cardoso Eisswein é estudante de Psicologia e bolsista de Iniciação Científica do CNPq na Universidade do Vale do Rio dos Sinos (UNISINOS), São Leopoldo, RS.

E-mail: georgius.esswein@gmail.com

Nathália Bohn da Silva é estudante de Psicologia e bolsista de Iniciação Científica da FAPERGS na Universidade do Vale do Rio dos Sinos (UNISINOS) - São Leopoldo, RS.

E-mail: nathaliabsv@gmail.com

Gabriel Soares Carvalho Bernardi é estudante de Psicologia e bolsista de Iniciação Científicado CNPq na Universidade do Vale do Rio dos Sinos (UNISINOS).

E-mail: gscb3@hotmail.com

Ana Calderón é psicóloga formada pela Universidade do Chile, possui título de mestre e doutor pela University College of London, UK (2014) e atua na área de clínica e de pesquisa em Psicanálise.

E-mail: anacalderonk@gmail.com

Contato com os autores:

Silvia P. C. Benetti

Rua Riveira, 150/301

Porto Alegre-RS, Brasil

CEP: 90670-150 
